\title{
THE USE OF EXTRACELLULAR AND INTRACELLULAR EMULSIFIERS FROM YEASTS IN WHIPPED CREAM PRODUCTION
}

\author{
AMER, ABEER E. A. ${ }^{1}$, SOAD A. SHERIF ${ }^{1}$, I. M. ROUSHDY ${ }^{2}$ \\ AND M. N. I. EL- MAGDOUB ${ }^{2}$ \\ 1. Dairy Microbiology Department, Animal Production Research Institute, ARC, \\ Dokki, Giza \\ 2. Food Science Department, Faculty of Agriculture, Ain Shams University, Cairo
}

(Manuscript received 30 December 2008)

\begin{abstract}
The main objective of this study was to manufacture whipped cream using different ratios of extracellular bioemulsifiers, which was produced by Candida utilis EMCC 120 and intracellular bioemulsifiers by Saccharomyces cervisiae EMCC 69. The results showed that using of the extracellular bioemulsifiers increased viscosity by increasing the added ratio of extracellular bioemulsifier to the whipped cream. The foam expansion values increased by increasing the added ratio of bioemulsifier to the whipped cream being the highest in the treatment with $0.3 \%$ of extracellular bioemulsifier. The foam stability values increased by increasing the ratio of bioemulsifier added to the whipped cream being the highest in the treatments with $0.3 \%$ of extracellular bioemulsifier. Also it was found that the foam stability values increased by increasing the ratio of intracellular bioemulsifier added to the whipped cream being the highest in the treatments with $0.3 \%$ of intracellular bioemulsifier.

Generally using of the extracellular bioemulsifiers in the manufacture of whipped cream improved whipping qualities of whipped cream and gave smoother body and texture. The preferable concentration of bioemulsifier produced by $S$. cereviciae EMCC 69 or C. utilis EMCC 120 was $0.3 \%$ which enhanced viscosity, foam expansion and foam stability, and eventually more acceptable to consumers was achieved.
\end{abstract}

\section{INTRODUCTION}

The manufacture of whipped cream, whether used by the housewives or by bakers for cakes. etc., is an important part of the cream industry. Most emulsifiers used in whipped cream are of unnatural origin. Microbial emulsifiers are of commercial interest for use as emulsifying agents. Whipped cream is not an everyday purchase in most housewives and is often used for special occasions. Consumers and the dairy industry have certain expectations for the quality of whipped cream with regard to 
taste, shelf-life and whipping characteristics. Whipping characteristics recognized within the industry are speed of whipping, overrun, firmness of whipped product, and stability (Mulder and Walstra 1974). The whipping process forms air cells that are stabilized at the air-water interface by fat globules (Thome and Eriksson 1973, Mulder and Walstra 1974, Muir et. al., 1983, Walstra Jennes 1984 and Towler 1986,). During whipping, the globules attach to air bubbles, as these air bubbles break and coalesce, the fat clumps. As whipping continues, air cells become smaller and more numerous, fat clumping continues, and the foam increases in volume and rigidity. If whipping continues still further, the fat clumps become so large they rupture the lamellae that enclose the air cells. Air bubbles start to coalesce, overrun decreases, and churning results.

Researchers agree that milk fat content, cream temperature, homogenization and pasteurization conditions, and presence of stabilizers and emulsifiers influence whipping creams functional properties (Mulder and Walstra 1974, Muir et al., 1983, Walstra and Jennes 1984).

On the other hand, extracellular emulsifier and intracellular emulsifier have a number of advantages over the other sources of emulsifier (biological, chemical or synthetic) because of their biodegradable, nature effectiveness, wide range of $\mathrm{pH}$, temperature and osmotic pressure. We have used a yeast strain Candida utilis EMCC 120 and Saccharomyces cervisiae EMCC 69 to produce a food grade extracellular and intracellular bioemulsifiers. Therefore, the aim of this work was to study the behavior of this new extracellular and intracellular bioemulsifiers on Whipped cream production.

\section{MATERIALS AND METHODS}

\section{Materials}

\section{Yeast Strains}

Eleven yeast strains were used in this study. Candida utilis NCYC 769 (EMCC 120), Candida kefyr NCYC 744 (EMCC 68), Creptococcus marinus NCYC 784 (EMCC 121), and Pichia anomala NCYC 20 (EMCC 121) (National Collection of Yeast Cultures, Research Park Colney, Norwich NR4 7UA, U.K.) Saccharomyces cerevisiae ATCC 287 (EMCC 69), Saccharomyces cerevisiae ATCC 4126 (EMCC 71), and Candida bombicola ATCC 22214 (EMCC 91). Candida utilis NRRL Y-900 (EMCC 41). Candida tropicalis DSM 70156 (EMCC 2) (Deutsche Sammlung von Mikroorganismen, Grtmany). All strains were kindly obtained from the Egyptian Microbial Culture Collection, Cairo MIRCEN, Faculty of Agriculture, Ain Shams University, Cairo, Egypt Commercial two strains of baker's (Saccharomyces cerev) yeast were obtained from the local market.

All strains were used throughout this work and were maintained on malt extract medium and stored at $4^{\circ} \mathrm{C}$. 
Fresh Cream 35\% fat was mechanically separated from the fresh buffalo's milk that obtained from the herd of the Dairy cattle at the Faculty of Agriculture, Ain Shams University.

Commercial grade granulated sucrose produced by Sugar and Integrated Industries Co. at Hawamdia was obtained from the local market. Gelatin was obtained from the local market.

Vanilla (Chem. Rein 100\%) made by Boehringer Manheim GMB, Germany was obtained from the local market. Emulsifier mono-glyceride (Glycerol monoleate) (GMO) was obtained from the local market.

Chemicals used in this study were of the analytical grade.

\section{Fermentation Process}

Erlenmeyer flasks $(500 \mathrm{ml})$ containing $100 \mathrm{ml}$ of Modified Czapek's yeast broth were inoculated with $2 \%$ of $24 \mathrm{~h}$ active culture and incubated for 3 days at $25^{\circ} \mathrm{C}$ in a shaking water bath with agitation at $200 \mathrm{rpm}$ for $60 \mathrm{~h}$.

Two strains of yeasts Candida utilis EMCC 120 and Saccharomyces cervisiae EMCC 69 were tested on one liter Modular fermentor (Mini Bioreactor, A. Gallen Kamp \& Co. Ltd.) operated at $25^{\circ} \mathrm{C}$ and $500 \mathrm{rpm}$ for Candida utilis EMCC 120 and at $28^{\circ} \mathrm{C}$ and 300 rpm for examining the strains ability to the production of significant amounts of the emulsifying agent.

\section{Emulsifier extraction}

The intracellular emulsifying agent was extracted from cells crop by heat extraction procedure of Cameron et al., (1988). The extracellular bioemulsifier was extracted from cell free extract as recirculate over modified cellulose ultrafiltration disc with magnetic sterrier, filters with a cut-off of 10000 Dalton to collect the extracellular yield with a molecular mass over 5000 Dalton. Cells crop will be collected by centrifugation, at $5000 \mathrm{xg}$ for $20 \mathrm{~min}$ at $4{ }^{\circ} \mathrm{C}$. The retentate was used as extracellular bioemulsifier.

\section{2-Manufacture of whipped cream}

Fresh cream $35 \%$ fat was mixed with additives [10 \% sucrose, $0.3 \%$ gelatin as a stabilizer and $0.3 \%$ commercial emulsifier were used (glycerol monooleate). Extracellular bioemulsifier was added at levels of $0.05,0.1$ and $0.2 \%$, and intracellular bioemulsifiers was added at levels of $0.05,0.1$ and $0.2 \%$ respectively. Extracellular bioemulsifiers from Saccharomyces cervisiae EMCC 69 and Candida utilis EMCC 120).. The mix was divided into 4 portions, the first was processed as control and was manufactured using $0.3 \%$ Glycerol monoleate (a commerical emulsifier) The other portions were processed using $0.1,0.2$ and $0.3 \%$ extracellular and intracellular bioemulsifier. Every treatment was pasteurized at $85^{\circ} \mathrm{C}$ for $10 \mathrm{~min}$, then cooled to 5 ${ }^{\circ} \mathrm{C}$ and aged at that temperature for overnight to the whipping treatment. 


\section{Methods of analysis}

The following parameters were determined in the whipped cream:

\section{Measurement of the $\mathrm{pH}$ Value}

The $\mathrm{pH}$ value was determined electrometrically using glass electrode $\mathrm{pH}$ meter 7010 Electronic Instruments Limited.

\section{Viscosity measurement}

Viscosity of whipped cream was determined according to Bourne (1982) using Hopppler viscometer Type BH No. 9367 at $20^{\circ} \mathrm{C}$.

\section{Whipping properties}

Foam expansion and foam stability have been suggested as the indices of whipping properties according to Yasumatsu et al., (1972).

\section{Organoleptic Evaluation}

Organoleptic properties of different whipped cream treatment were carried out by panalists from the Food Science Department, Faculty of Agriculture, Ain Shams University. Scoring was carried out according to the score card suggested by (Nelson and Trout, 1964), The temperature of the products was $15+1{ }^{\circ} \mathrm{C}$ during evaluation.

\section{RESULTS AND DISCUSSION}

Of the 11 products tested, eight had emulsifying properties that were better than those of commonly used as food emulsifiers' mono-glyceride (Glycerol monooleate). Candida utilis EMCC 120 were selected for further study due to the excellent emulsification properties of its extracellular products and the food grade status of the yeasts. Saccharomyces cervisiae EMCC 69 was selected for further study due to the excellent emulsification properties of its intracellular products and the food grade status of the yeasts. One extraction method was used to obtain emulsifying agent from cells of C. utilis EMCC 120, S. cervisiae EMCC 69 and commercial strain of bakers' yeast (1). In this method washed cells were autoclaved in neutral buffer. An emulsifying agent was released into the aqueous medium was concentrated by ultrafiltration. The purified emulsifier was precipitated with 3 volumes of ethanol containing $1 \%$ acetic acid. Data in Table (1) clearly indicated that carbohydrate and protein contents of the purified ultrafiltrated emulsifier were, respectively, $77.87 \%$ and $25.67 \%$ for S. cervisiae EMCC 69, 65.5\% and $10.63 \%$ for C. utilis EMCC 120 and $39.30 \%$ and $32.76 \%$ for commercial strain of bakers' yeast (1). Many yeast species have a cell wall, containing glycoprotein with a structural role, similar to that of $C$. utilis, S. cervisiae and bakers' yeast (Cameron et al. 1988, Ogawa et al. 1990, Roushdy, 1997). The presence of proteinaceous material covalently bound to a polysaccharide-based bioemulsifier would lead to erroneous conclusions about the emulsification properties of that polysaccharide as proteins are known for their surfactancy (Patel and Fry, 1987). 
Table 1. Biomass production, yield and characterization of intracellular bioemulsifier (IBE) extracted from Saccharomyces cerevisia S. cerevisiae EMCC 69, Candida utilis EMCC 120, and two commercial strains of baker 's by modified czapek"s yeast broth at $25{ }^{\circ} \mathrm{C}$ for $72 \mathrm{~h}$.

\begin{tabular}{|c|c|c|c|c|c|c|c|c|c|}
\hline \multirow{2}{*}{ Yeast strains } & \multirow{2}{*}{$\begin{array}{c}\text { Biomass } \\
(\mathrm{g} / \mathrm{l})\end{array}$} & \multicolumn{4}{|c|}{ Crude emulsifier } & \multicolumn{4}{|c|}{ Purified emulsifier } \\
\hline & & $\begin{array}{c}\% \text { Yield } \\
\text { ( } \mathrm{g} / \mathrm{g}) \text { [wet } \\
\text { wt] of cells } \\
\text { of } \\
\text { bioemulsifier }\end{array}$ & IBE $(\mathrm{g} / \mathrm{l})$ & $\begin{array}{c}\text { \% } \\
\text { protein } \\
\text { content }\end{array}$ & $\begin{array}{c}\% \\
\text { carbohydrate } \\
\text { content }\end{array}$ & $\begin{array}{c}\text { \% Yield } \\
\text { ( } \mathrm{g} / \mathrm{g}) \text { [wet } \\
\text { wt] of cells } \\
\text { of } \\
\text { bioemulsifier }\end{array}$ & $\operatorname{IBE}(\mathrm{g} / \mathrm{l})$ & $\begin{array}{l}\% \text { protein } \\
\text { content }\end{array}$ & $\begin{array}{c}\% \\
\text { carbohydrate } \\
\text { content }\end{array}$ \\
\hline $\begin{array}{c}\text { C. utilis } \\
\text { EMCC } 120\end{array}$ & 13.8 & 6.23 & 0.86 & 3.171 & 27.5 & 3.1 & 0.52 & 10.63 & 65.5 \\
\hline $\begin{array}{c}\text { S. cerevisiae } \\
\text { EMCC } 69\end{array}$ & 7 & 8 & 4.4 & 15.03 & 39.52 & 4.5 & 2.66 & 25.67 & 77.87 \\
\hline $\begin{array}{c}S . \\
\text { cerervisiae } \\
\text { EMCC } 71\end{array}$ & 6.5 & 7.88 & 1.3 & 3.23 & 36.71 & 2.52 & 0.74 & 15.84 & 75.65 \\
\hline $\begin{array}{c}\text { Commerical } \\
\text { strain of } \\
\text { baker' } \mathbf{S} \\
\text { yeast }(1) \\
\end{array}$ & 15.2 & 25 & 3.8 & 15.43 & 17.8 & 12.8 & 1.87 & 32.76 & 39.30 \\
\hline $\begin{array}{c}\text { Commerical } \\
\text { strain of } \\
\text { baker' } \mathrm{s} \\
\text { yeast (2) }\end{array}$ & 5 & 24.33 & 1.216 & 3.3152 & 36.6 & 10.85 & 0.86 & 14.63 & 50.45 \\
\hline
\end{tabular}

IBE: intracellular bioemulsifier 
The $\mathrm{pH}$ values of whipped cream samples reported in Table (2) were 6.66, $6.64,6.63,6.61,6.59,6.54$ and 6.68 with $0.1,0.2$ and $0.3 \%$ S. cerevisiae EMCC 69 of intracellular bioemulsifier produced by $S$. cerviciae EMCC 69 or extracellular bioemulsifier produced by C. utilis EMCC 120 respectively. Moreover, the replacement of extracellular or intracellular bioemulsifiers in the whipped cream did not lead to any changes in the $\mathrm{pH}$ values.

Viscosity values of whipped cream samples reported in Table (2) were $248.8,425.4,465.4,520.4,285.3,322.6$ and $395.4 \mathrm{cp}$ with $0.1,0.2$ and $0.3 \%$ of extracellular bioemulsifier produced by $C$. utilis EMCC 120 or intracellular bioemulsifiers produced by $S$. cerviciae EMCC 69 respectively. From the data presented it can be seen that the control sample with $0.3 \%$ glecerol monoolate had lower viscosity value than that with intracellular or extracellular bioemulsifier.

Foam expansion values of whipped cream treatments are shown in Table (2), which were $145.5,159,160,162,143,146$ and 150 for control and samples with 0.1, 0.2 and 0.3 of extracellular or intracellular bioemulsifier respectively. From the data obtained it can be seen that the control sample with $0.3 \%$ glecerol monoolate had lower foam expansion values than that with intracellular or extracellular bioemulsifier. Among treatments with bioemulsifier, the foam expansion values increased by increasing the ratio added of bioemulsifier to the whipped cream being the highest in the treatment with $0.3 \%$ of extracellular bioemulsifier.

Regarding to the foam stability of whipped cream, it seems from the data that, the foam stability increased significantly as the replacement level of intracellular or extracellular bioemulsifiers was raised. being the highest in the treatments with $0.3 \%$ of extracellular bioemulsifier 
Table 2. Physicochemical and whipping properties of whipped cream with different levels of intracellular (Saccharomyces cervisiae EMCC 69) and extracellular (candida utilis EMCC 120) bioemulsifiers.

\begin{tabular}{|c|c|c|c|c|c|c|c|}
\hline \multirow[b]{2}{*}{ Property } & \multirow{2}{*}{$\begin{array}{c}\text { Control } \\
0.3 \% \\
\text { GMO }\end{array}$} & \multicolumn{3}{|c|}{ Extracellular bioemulsifiers \% } & \multicolumn{3}{|c|}{ Intracellular bioemulsifies \% } \\
\hline & & 0.1 & 0.2 & 0.3 & 0.1 & 0.2 & 0.3 \\
\hline $\mathrm{PH}$ & 6.66 & 6.64 & 6.63 & 6.61 & 6.59 & 6.54 & 6.68 \\
\hline $\begin{array}{c}\text { Viscosity } \\
\text { (cp) }\end{array}$ & 248.8 & 425.4 & 465.4 & 520.4 & 285.3 & 322.6 & 395.4 \\
\hline $\begin{array}{c}\text { Foam } \\
\text { expansion } \\
\text { (overrun) } \\
(\%)\end{array}$ & 145.5 & 159 & 160 & 162 & 146 & 146 & 150 \\
\hline $\begin{array}{c}\text { Foam } \\
\text { stability } \\
\text { after: }\end{array}$ & & & & & & & \\
\hline $15 \min$ & 155.5 & 158 & 160 & 161 & 142 & 145 & 150 \\
\hline $30 \mathrm{~min}$ & 145 & 155 & 158 & 157 & 140 & 144 & 145 \\
\hline $60 \min$ & 148 & 152 & 153 & 155 & 138 & 143 & 146 \\
\hline $90 \mathrm{~min}$ & 146 & 150 & 151 & 153 & 137 & 142 & 144 \\
\hline $120 \mathrm{~min}$ & 140 & 150 & 150 & 151 & 134 & 141 & 143 \\
\hline
\end{tabular}

GMO: (glecerol monoolate).

\section{Organoleptic profile of whipped cream}

The average sensory score points of different whipped cream treatments manufactured with and without the addition of intracellular and extracellular bioemulsifiers are shown in Table (3).

It is obvious from the data that the control sample had total score of 81.5 points. However, the whipped cream containing $0.1,0.2$ and $0.3 \%$ of intracellular and extracellular bioemulsifiers possessed total score points of $91,91.5,93.5,88,89$ and 91 respectivly.

From the results it could be noticed that the lowest score of flavour was obtained by control treatment but the highest score of flavour was obtained for treatment with extracellular bioemulsifiers produced by $C$. utilis EMCC 120 . The best was the treatment with $0.3 \%$. Regarding the body and texture criteria of whipped cream as affected by the replacement level of extracellular bioemulsifiers the data revealed that addition of commercial emulsifier by $0.3 \%$ of the extracellular bioemulsifiers produced by $C$. utilis EMCC 120 led to improve in body and texture whilst the score of body and texture decreased as the replacement level decreased than $0.2 \%$. The general appearance score was higher for treatment with $0.3 \%$ of extracellular bioemulsifiers produced by $C$. utilis EMCC 120 than that of $0.1 \%, 0.2 \%$ and control treatments. From 
the foregoing results, it could be concluded that, the ratio $0.3 \%$ of extracellular bioemulsifiers produced by $C$. utilis EMCC 120 was the best treatments.

Table 3. Organoleptic properties of whipped cream with different levels of intracellular (Saccharomyces cervisiae EMCC 69) and extracellular (candida utilis EMCC 120) bioemulsifiers.

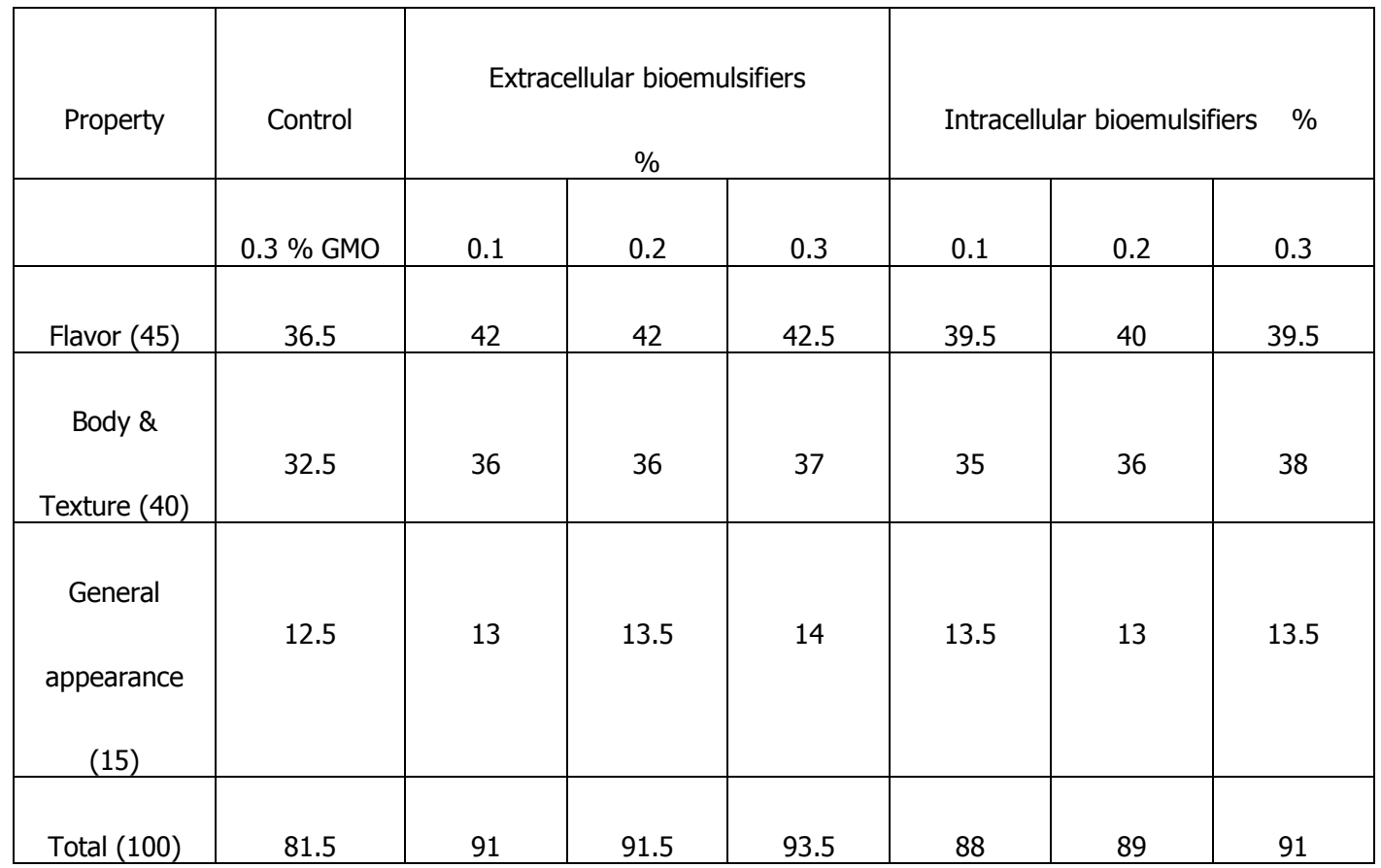

GMO: (glecerol monoolate).

\section{CONCLUSION}

Adding exteracellular bioemulsifier produced by C. utilis EMCC 120 at the concentration of $0.3 \%$ improved the viscosity and Foam expansion (overrun), consequently more acceptable to consumers was achieved. In addition, high quality whipped cream with preferable texture and consistency, were produced with adding interacellular bioemulsifier produced by $S$. cerviciae EMCC 69 and exteracellular bioemulsifier produced by $C$. utilis EMCC 120 to the cream used for making whipped cream at the rate of $0.3 \%$. 


\section{REFERENCES}

1. Bourne, M. C. 1982. In, Food texture and viscosity concept and Measurement. Academic Press Inc., New York, USA, p.p. 240-244.

2. Cameron, D. R., D. G Cooper and R. J. Neufeld. 1988. The mannoprotein of Saccharomyces cervisiae is an effective bioemulsifier. American Society for microbiology. 54: (6), 1420-1425.

3. Muir, D. D., J. M. Banks, A. K. Powell and A.W. Sweetsur. 1983. Milk composition, manufacturing properties. Proc. Nutr. Soc. 42:385.

4. Mulder, H. and P. Walstra. 1974. The milk fat globule. Commonw. Agric., Bur., Farmham Royal, Buckinghamshire, Engl.

5. Nelson, J. A. and G. M. Trout. 1964. "Judging Dairy products". $4^{\text {th }}$ ed. The olsen publishing co. Milwaukee, wiss USA.

6. Ogawa, K. K., K. T. Matsuda and S. Kiyo-Oka. 1990. Immunochemical analysis of the glucomannan from Candida utilis. Agriculture Biological Chemistry, 54, 593597.

7. Patel, P. D. and J. C. Fry 1987. The search for standardized methods for assessing protein functionality. Development in Food Proteins (Hudson, B. J. F., ed.). Elsevier Applied Science, London, pp. 299-333.

8. Roushdy, I. M. 1997. Bioemulsifying agent from yeast grown in milk permeate. Arab University Journal of Agriculture Science, Ain Shams Univ., Cairo, 5 (2) 265274.

9. Thome K. E. and G. Eriksson. 1973. The foaming properties of cream. 1. Substances in milk increasing the whippability of creams. Milchwissenschaft 28:502.

10. Towler, C. 1986. Measurement of whipping properties of cream and the effect of cream variation on whipping. N. Z. J. Dairy Sci. \& Technolo. 21:79.

11. Walstra, P. and R. Jennes. 1984. Dairy Chemistry and physics. John Willy and Sons, New York, NY.

12. Yasumatsu, K., K. Sawada, S. Moritaka, M. Misaki, J. Toda, T. Wada and K. Iski. 1972. Whipping and emulsifying properties of soybean products. Agr. Biol. Chem., $36: 719$. 


\section{إستخدام مواد الاستحلاب الخارجية و الاخلية من الخمائر}

\section{فى إنتاج القشدة المخفوقة}

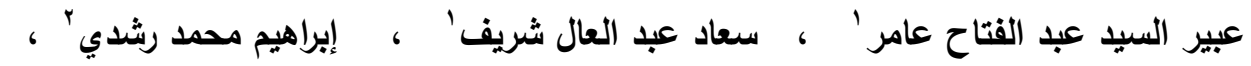 محمد نبيل إبراهيم المجدوب٪
1 - قسم المبكروبيولوجى - معهد بحوث الإنتاج الحيوانى، مركز البحوث الزراعية - الدقى - حيزة .

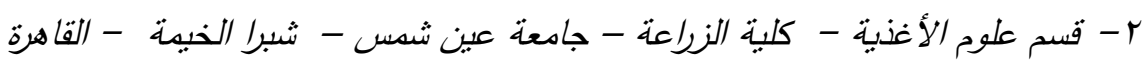

yeast Modified Czapek's تهدف هذه الدراسة إلى تتمية سلالتنين من الخميرة في بيئة

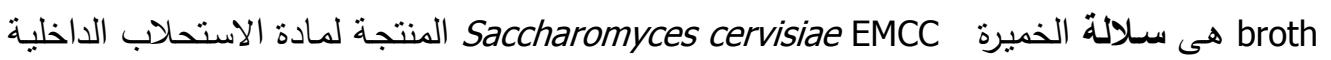
أو مادة الاستحلاب الخارجية المنتجة بواسطة سلالة الخميرة 120 Candida utilis EMCC و قد تم فصل هذه المواد عن طريق الترشيح الدقيق ( الفائق) Ultra Filtration وتم استخدام مادة الاستحلاب

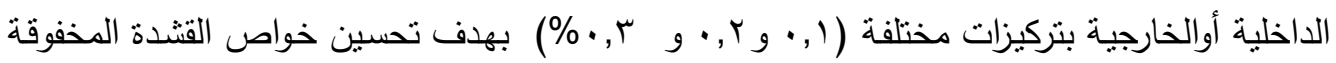
الناتجة بالمقارنة بالكنترول. و قد أظهرت النتائج أن استخدام مادة الاستحلاب الخارجية عملت على زيادة اللزوجة بزيادة النسبة المضافة من مادة الإستحلاب الميكروبية الخارجية في القتدة المخفوقة وأن هناك أيضا زئا زيادة تدريجيـة في الريع و ثبات الرغوة بزيادة النسبة المضـافة من مادة الإستحلاب الميكروبية الخارجيـة

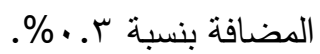

و بصفة عامة قد أظهرت النتائج المتحصل عليها عند صناعة القتدة المخفوقة أن استخدام مادة الاستحلاب المنتجة بواسطة سلالة الخميرة 69 Saccharomyces cervisiae EMCC أو المنتجة

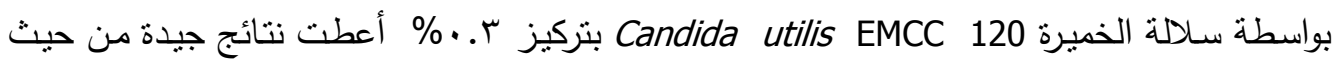

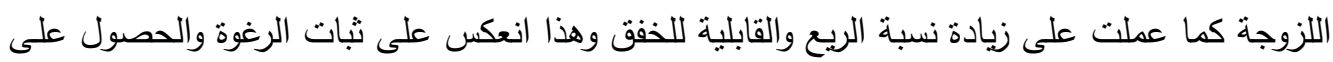
أفضل الدرجات عند التحكيم الحسي لها. 